\title{
Molecular detection of Herpes Simplex Virus-2 gpG gene among People of different health status in parts of Katsina State
}

\author{
* ${ }^{1}$ Hayatudeen M.R, and ${ }^{2}$ Aminu M, \\ 1 Department of Microbiology, \\ Umaru Musa Yar Adua University, \\ Katsina.
}

2 Department of Microbiology, Ahmadu Bello University, Zaria.

Email :hayatudeen.muhammad@umyu.edu.ng

\begin{abstract}
Although herpes simplex virus (HSV) has been detected in the blood of immune compromised patients and in those with disseminated disease, the extent to which the virus may be present in the blood during a localized infection is still unknown. Literature on patterns of HSV-2 shedding at the prodromal stage of the disease during recurrences and also during asymptomatic periods is still lacking. The present study aimed at the detection of HSV-2 gpG gene in the serum during current acute herpes genitalis using a highly sensitive technique, the polymerase chain reaction (PCR). The study included 24 people with different health status that included pregnant women, HIV positive patients, feverish patients and healthy individuals. Using PCR, HSV-2 gpG gene were detected in the plasma of 5 pregnant women (83.3\%) and one HIV positive patient (16.7\%). Analysis by Chi-square indicated there were a good statistical significant difference between the presence of HSV-2 DNA among the respondents included in this study $(P<0.05)$. Patient's age, and gender had no statistically significant effect on the presence of the HSV-2 DNA in the plasma. It is concluded that HSV-2 viremia exist during primary exposure to thevirus and recommended avoidance of blood transfusion during acute attacks of herpes genitalis.
\end{abstract}

Keywords: DNA; Genitalis; Herpes simplex; PCR; Plasma; Viremia.

\section{INTRODUCTION}

Herpes simplex viruses (HSV) are large double-stranded DNA virus belonging to Alphaherpesvirus subfamily of Herpesviruses surrounded by an envelope of glycoprotein (Ryan and Ray, 2004).They are proficient in promoting cell death upon infection and in establishing latency in sensory gangliaand replicating in epithelial cells during primary and recurrent infection (Heldwein and Krummenacher, 2008).

Herpes Simplex Virus-2 is a common human pathogen that can cause primary and recurrent infections of mucous membranes (Gupta et al., 2007). Primary HSV-2 infections occurwhen there are no pre-existing antibodies against HSV-2 (Tronstein et al., 2011). Recurrence takes place, when HSV reactivates in sacral ganglia(Barnabas et al., 2011).Herpes Simplex Virus Type-2 (HSV-2) can be horizontally transmitted through sexual contacts (Hayatudeen and 
Abdullahi, 2018) and may also be transmitted vertically during childbirth from mother to child (Corey and Wald, 2009).

Herpes Simplex Virus type 2 (HSV-2) is a significant public health problem as it is the leading cause of genital ulcerative disease (GUD) that is common both in industrialized and developing countries (Bradley et al., 2014). Infection with HSV-2 is life-long and once established, there is currently no treatment to eliminate it (Wald, 2008). Majority of the infections are asymptomatic and this enhances HSV-2 transmission because asymptomatic individuals shed the virus and transmit the disease (Kriebs, 2008).

In addition, HSV-2 DNA was detected by PCR in the serum during acute herpes genitalis or this viremia may be responsible for the development of disseminated disease and may play a role in the pathogenesis (Brice et al., 1999). Viremia of HSV-2 is more frequent than previously appreciated, and the detection of HSV-2 DNA in the plasma is a useful diagnostic tool, particularly in infants (Diamond et al., 1999). The aim of this study was to detect HSV-2 DNA in the Plasma during primary infection herpes genitalis using a highly sensitive technique.

\section{MATERIALS AND METHOD}

\section{Study area}

The study was carried out in Katsina State located at the extreme northern margin of Nigeria. The State covers a total area of about $23,938 \mathrm{sqkm}(3,370 \mathrm{sq})$ with a total population of $5,801,584$ people, going by 2006 census. It lies between latitudes $11^{\circ} 08^{\prime} \mathrm{N}$ and $13^{\circ} 22^{\prime} \mathrm{N}$ and longitudes $6^{\circ} 52^{\prime} \mathrm{E}$ and $9^{\circ} 20^{\prime} \mathrm{E}$. The State is bounded by Niger Republic to the north, by Jigawa and Kano States to the east, by Kaduna State to the south and by Zamfara State to the west. Katsina State has predominantly Hausa-Fulani indigenes. About $75 \%$ of the people are farmers and others are traders and livestock owners. There are also some other Nigerian settlers from southern Nigeria especially the Yoruba and Igbo in the State.The State has thirty four (34) local government areas which are divided into three (3) senatorial zones according to their geographical locations namely; Funtua zone, Katsina zone and Daura zone (Hayatudeen et al., 2018).

\section{Study population}

The study population comprised of males and females among HIV patients, pregnant women, feverish patients, and healthy individuals.

\section{Sample collection}

A total of 24 blood samples was collected aseptically using $5 \mathrm{ml}$ syringe from those who gave consent. The $3 \mathrm{ml}$ was allowed to clot for 30 minutes and centrifuged at $1000 \mathrm{rmp}$ for 10 minutes. The serum was carefully removed with a transfer pipette and transferred aseptically to a sterile labeled serum storage screw-capped container. It was stored at $-20^{\circ} \mathrm{C}$ in a refrigerator until analyzed.

\section{DNA Extraction}

A total of 24 whole blood of HSV-2 IgM seropositive samples were subjected to HSV-2 DNA extraction using commercially ZR Viral DNA Kit ${ }^{\mathrm{TM}}$ extraction kit manufactured by Zymo Research Company, USA. The DNA was extracted using $200 \mu 1$ reconstituted sample. In a $1.5 \mathrm{ml}$ microcentrifuge tube, $400 \mu \mathrm{l}$ of ZR Viral DNA Buffer was added to $100 \mu \mathrm{l}$ plasma. It was mixed briefly by vortexing and allowed to stand at room temperature for 10 minutes. The mixture was transferred to a Zymo-Spin ${ }^{\mathrm{TM}}$ IC Column in a Collection Tube and centrifuged 
for 1 minute. The flow through was discarded from the collection tube then $300 \mu 1$ DNA wash buffer was added to the column centrifuged for 1 minute. The flow through was discarded and the step repeated. The Zymo-Spin ${ }^{\mathrm{TM}}$ IC Column was placed into a microcentrifuge tube. Finally $10 \mu \mathrm{l}$ DNA Elution Buffer was added directly to the column matrix. It was allowed to stand at room temperature for one minute and centrifuged for 1 minute to elute the DNA (Zymo Research, 2014).

\section{The PCR Procedures}

Primers for HSV-2 were designed by DNA synthesizer (Beckman) to target glycoprotein G gene. The sequences of the primers used are shown in Table 1.The PCR was done in a total volume of $100 \mu \mathrm{l}$ reaction mixture containing: 10x PCR buffer $(10 \mu \mathrm{l}), \mathrm{MgCl}_{2}(25 \mathrm{mM}) 4 \mu \mathrm{l}$, dNTPs $(2.5 \mathrm{mM}) 8 \mu \mathrm{l}$, primer HS13 (50 Pmol/ $\mu \mathrm{l}) 2 \mu \mathrm{l}$, primer HS14 (50 Pmol/ $\mu \mathrm{l}) 2 \mu \mathrm{l}$, Taq DNA polymerase $(5 \mathrm{U} / \mu \mathrm{l}) 1 \mu \mathrm{l}, \mathrm{H}_{2} \mathrm{O} 63 \mu \mathrm{l}$ and extracted DNA $(10 \mu \mathrm{l})$.Initialization step occurs at temperature of $94^{\circ} \mathrm{C}$ for at least 3 mins, for denaturation step occur at $95^{\circ} \mathrm{C}$ for $30 \mathrm{sec}$, for annealing step at $55^{\circ} \mathrm{C}$ for $40 \mathrm{sec}$, for extension step occurs at $72^{\circ} \mathrm{C}$ and final elongation step at $74^{\circ} \mathrm{C}$ for $15 \mathrm{mins}$.

\section{Detection of the amplified DNA}

The HSV-2 DNA amplified products were separated on $2 \%$ agarose gel stained with ethidium bromide for visualization of the DNA. Positive control and negative control samples were per-formed in every run. The positive cases showed clear bands at $120 \mathrm{bp}$.

Table 1: Primers for the target of gGP gene

\begin{tabular}{|c|c|c|c|}
\hline Primers & Sequences $\left(5^{\prime}-3^{\prime}\right)$ & Amplicon Size & Reference \\
\hline Forward & 5'-TACGCTCTCGTAAATGCTTC- 3' & $120 b p$ & Yun et al. (2014) \\
\hline Reversed & 5'- GCССАСССТССТАСССАСАA- 3' & $120 b p$ & Yun et al. (2014) \\
\hline
\end{tabular}

\section{RESULTS}

General characteristics of the respondents recruited in this study are shown in Table 2. The study population age ranged between 13years and 63 years. Out of the 24 respondents included in this study 12 equal numbers of females and males are involved in this study. The respondent represent people with different health status of HIV patients, feverish patients, pregnant women and apparently healthy. Most of the patient presents a typical diagnostic feature of herpes genitalis.

Result and analysis in relation to the detection of Herpes simplex virus-2 DNA from the plasma of the respondents is shown in Table 3. An overall percentage of occurrence $25 \%$ $(6 / 24)$ was recorded in this study. However, the higher percentage of occurrence of $83.3 \%$ $(5 / 24)$ was seen among pregnant women compared to $16.7 \%(1 / 24)$ recorded among HIV patients. Both Feverish patients and apparently healthy had recorded $0.0 \%(0 / 24)$ no any detection of HSV-2 DNA. There were statistical significant difference $\left(\chi^{2}=5.415, \mathrm{df}=3, \mathrm{p}=\right.$ 0.0000 ) between their percentage of occurrence of HSV-2 DNA among the respondent recruited in this study. 
Molecular detection of Herpes Simplex Virus-2 gpG gene among People of different health status in parts of Katsina State

Table 2: Clinical Manifestations based on Age and Gender of the tested individuals

\begin{tabular}{|c|c|c|c|c|}
\hline Location & Age & Gender & Respondent & Presentation \\
\hline \multirow[t]{4}{*}{ Katsina } & 34 & $\mathrm{~F}$ & FE & Lesions \\
\hline & 23 & $\mathrm{~F}$ & PG & Lesions \\
\hline & 31 & M & $\mathrm{HV}$ & Lesions \\
\hline & 24 & M & $\mathrm{AH}$ & Whitlow \\
\hline \multirow[t]{4}{*}{ Dutsinma } & 21 & M & $\mathrm{HV}$ & Rashes \\
\hline & 53 & $\mathrm{~F}$ & PG & Lesions \\
\hline & 26 & $\mathrm{~F}$ & $\mathrm{FE}$ & Blister \\
\hline & 19 & M & $\mathrm{AH}$ & Rashes \\
\hline \multirow[t]{4}{*}{ Daura } & 32 & $\mathrm{~F}$ & PG & Whitlow \\
\hline & 19 & M & $\mathrm{HV}$ & Lesions \\
\hline & 16 & $\mathrm{~F}$ & $\mathrm{FE}$ & Rashes \\
\hline & 25 & M & $\mathrm{AH}$ & Lesions \\
\hline \multirow[t]{4}{*}{ Baure } & 63 & $\mathrm{~F}$ & $\mathrm{FE}$ & Lesions \\
\hline & 56 & M & $\mathrm{HV}$ & Blister \\
\hline & 21 & $\mathrm{~F}$ & PG & Whitlow \\
\hline & 34 & M & $\mathrm{AH}$ & Whitlow \\
\hline \multirow[t]{4}{*}{ Funtua } & 45 & $\mathrm{~F}$ & $\mathrm{HV}$ & Blister \\
\hline & 34 & $\mathrm{M}$ & $\mathrm{FE}$ & Lesions \\
\hline & 26 & $\mathrm{~F}$ & PG & Lesions \\
\hline & 32 & M & $\mathrm{AH}$ & Rashes \\
\hline \multirow[t]{4}{*}{ Malumfashi } & 25 & $\mathrm{~F}$ & PG & Rashes \\
\hline & 43 & M & $\mathrm{HV}$ & Lesions \\
\hline & 23 & $\mathrm{~F}$ & $\mathrm{FE}$ & Rashes \\
\hline & 27 & $\mathrm{M}$ & $\mathrm{AH}$ & Whitlow \\
\hline
\end{tabular}

Keywords: $\mathrm{F}=$ Female, $\mathrm{M}=$ Male, $\mathrm{PG}=$ pregnant, $\mathrm{HV}=\mathrm{HIV}, \mathrm{FE}=$ feverish patient $\mathrm{AH}=$ apparently healthy

Table 3: Percentage of occurrence of HSV-2 DNA based on the category of the respondent

\begin{tabular}{lccccc}
\hline Respondents & Number & \multicolumn{2}{c}{ PCR } & Chi-square & P-value \\
& & Positive (\%) & Negative (\%) & & 0.0000 \\
HIV Patients & 06 & $01(16.7)$ & $05(83.3)$ & 5.415 & \\
Pregnant & 06 & $05(83.3)$ & $01(16.7)$ & & \\
Feverish & 06 & $00(0.0)$ & $06(100.0)$ & & \\
Healthy & 06 & $00(0.0)$ & $06(100.0)$ & & \\
Total & 24 & $06(25.0)$ & $18(75.0)$ & & \\
\hline
\end{tabular}

Keyword: \%= Percentage of occurrence; $P \leq 0.05$ statistical significant

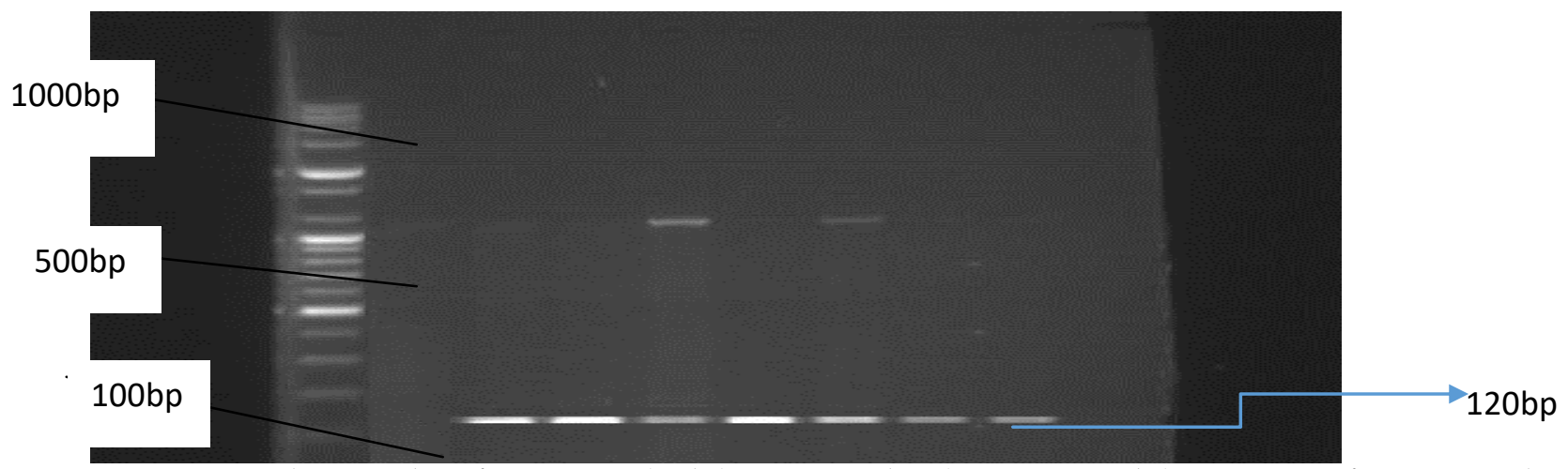

Fig.1. Agarose gel PCR product of HSV-2 DNA (120bp), M: PCR markers (1000, 500 \& 100 bp), L3-L8: cases of positive samples, L9: case of negative sample, L1: negative control, L2: positive control.

Keywords: $\mathrm{PC}=$ Positive Control; NC= Negative Control.

\section{DISCUSSION}

Results of the present study proved the presence of HSV-2 DNA in the serum denoting that a state of viremia existed at the time of specimen withdrawal in $25 \%$ of respondents. The 
results supported the postulation of the possible transmission of HSV-2 through blood transfusion Brice et al. (1999) who reported viremia in a minority $(20 \%)$ of their patients. This is consistent with the results of two other studies (Brice et al., 1992; Youssef et al., 2002) suggesting a higher prevalence of HSV-2 DNA in recurrent herpes infection. In one of these studies (Brice et al., 1992), HSV-2 DNA was detected in serum of seven patients with recurrent herpes genitalis during the active infection. This implies that there is verimia of HSV-2 infection therefore the virus can be easily transmitted by blood transfusion.

The fact that in our study HSV-2 DNA was not detectable in some plasma with herpes genitalis could be related to the differences in the investigated patients, the patients suffering from herpes genitalis in our study had no further manifestation despite blistering and redness; this is in contrary to what was described by Bezold et al. (2000) suffered from a more distinct clinical picture; and in all patients who were tested positive for HSV-2 DNA in serum (Youssef et al., 2008).

Another potential explanation is the PCR assay used. It is difficult to compare the analytical sensitivity of our PCR technique with those described previously van Doornum et al. (2003) and Weidmann et al. (2003). The point in time during an HSV-2 infection when a sample is taken might be also crucial for the detection of HSV-2 DNA in serum.

\section{CONCLUSION}

HerpesSimplexVirus type 2 DNA were detected indicated that there verimia of HSV-2 infection in $25.0 \%$ of the respondents recruited in this study. Pregnant women had higher verimia of HSV-2 infection while HIV patients had lowest. None of the apparently healthy people and feverish patients had HSV-2 verimia of infection. There is a statistical significant difference among HSV-2 DNA detection among the respondents. This study implies that these positive patients have been infected with the virus and had DNA of the virus circulating in the blood hence probable disseminated infection. The results highlight the potential public health impact of HSV-2 in Nigeria where anti-HSV-2 testing is not generally performed in all populations.

\section{RECOMMENDATION}

In view of the verimia of HSV-2 obtained in this study, there is need for public enlightenment on genital herpes, its mode of transmission and public health significance. HIV Patients and pregnant women should be tested for HSV-2 whenever they come for medical consultations to avoid devastating effect of genital herpes. Further, both government and private clinics should employ the screening of HSV-2 before transfusing blood. Further studies with larger sample size are recommended. Since infection with HSV-2 is life-long and has no known cure, primary prevention remains the mainstay of its control.

\section{REFERENCES}

Barnabas, R.V., Wasserheit, J.N., Huang, Y.D., Janes, H. Morrow, R. Fuchs, J. Mark, K.E., Casapia, M. Mehrotra, D.V., and Buchbinder, S.P. (2011). Impact of Herpes Simplex Virus type 2 on HIV-1 acquisition and progression in an HIV vaccine trial (the step study) Journal of Acquired Immune Deficient Syndrome, 57:238-244.

Bezold, G. Gottl"ober, P. Leiter, U. Kerscher, M. Krahn, G.and Peter, R.U. (2000). Quantitation of herpes simplex DNA in blood during aciclovir therapy with competitive PCR ELISA. Dermatology, 201:296-299. 
Bradley, H. Lauri, E. Theda, G. and Geraldine M.M. (2014). Seroprevalence of Herpes Simplex Virus Types 1 and 2-United States, 1999-2010, Journal of Infectious Diseases, 209:325-333.

Brice, S.L., Stockert, S.S., Jester, J.D., Huff, J,C., Bunker, J.D. and Weston, W.L. (1999). Detection of herpes simplex virus DNA in the peripheral blood during acute recurrent herpes labialis. Journal of the American Academy of Dermatology, 26:594-598.

Centers for Disease Control and Prevention, (2012). STD Curriculum for Clinical Educators. Genital Herpes simplex virus (HSV). Department of Health and Human Services, November CDC MMWR Morb Wkly; 7-36.

Corey, L. and Wald, A. (2009). "Maternal and Neonatal HSV Infections". New England Journal of Medicine, 361(14):1376-1385.

Diamond C, Mohan K, Hobson A, Frenkel L, Corey I (1999): Viraemia in neonatal herpes simplex virus infections, Pediatrician Infectious Disease Journal, 18: 487-489.

Gupta, R. Warren, T. and Wald A. (2007). Genital herpes. Lancet 370(95): 2127-2137.

Hayatudeen M.R, and Abdullahi S.(2018): Survey of Immunoglobulin G and M of Herpes Simplex Virus Type 2 among HIV Patients in some selected Hospitals of Katsina State, Quest Journals Journal of Medical and Dental Science Research, 5(5): 08-14.

Hayatudeen, M.R., Bashir, A. and Aminu, M. (2018): Seroprevalence of Herpes SimplexVirus Type 2 among Patients Presenting With Fever in Katsina State, Nigeria. Bayero Journal of Medical Laboratory Sciences. 3(1):1-9.

Heldwein, E.E., and Krummenacher, C. (2008). Entry of herpesviruses into mammalian cells. Cell Molecular Life Science, 65(11): 1653-1668.

Kriebs, I.M. (2008). Understanding Herpes simplex virus: Transmission, Diagnosis and considerations in pregnancy management. Midwifery Womens Health, 53(3): 202-208.

Rosenthal, M.S. (1999). From the Gynecological Source Book, 3rd ed article 59630, 1(2): 2-5.

Ryan, K.J., and Ray C.G, (2004). Genital Herpes as a public health problem. Sherris Medical Microbiology12(4): 555-562.

Tronstein, E. Johnston, C. Huang M.L., Selke, S. Magaret, A. and Warren, T. (2011). Genital shedding of herpes simplex virus among symptomatic and asymptomatic persons with HSV-2 infection. Journal of the American Medical Association, 305(14): 1441-1449.

Van Doornum, G.J., Guldemeester, J. Osterhaus, A.D., and Niesters, H.G. (2003). Diagnosing herpesvirus infections by real-time amplification and rapid culture. Journal of Clinical Microbiology, 45: 576-580.

Wald, A. and Link, K. (2008). Risk of human immunodeficiency virus infection in herpes simplex virus type-2 seropositive persons: a meta-analysis. Journal of Infectious Disease, 185: 45-52.

Weidmann, M. Ursula, M.K., and Frank T.H.(2003). Rapid detection of Herpes Simplex Virus; Journal of Clinical Microbiology, 41: 1565-1568.

Youssef, R. Shaker, O. Sobeih, S. Mashaly, H. and Mostafa, W.Z. (2002). Detection of herpes simplex virus DNA in serum and oral secretions during acute recurrent herpes labialis. The Journal of Dermatology, 29: 404-410.

Zymo Research (2014). ZR Viral DNA Kit ${ }^{\mathrm{TM}}$ Instructional Manual. Version. 1.1.3. Zymo Research Corp. www.zymoresearch.com. 